\title{
Metode Moment Invariant Geometrik untuk Menganalisis Jenis Daging Babi dan Daging Sapi
}

\author{
Oky Dwi Nurhayati ${ }^{\mathrm{a}^{*}}$, Isti Pudjihastuti ${ }^{\mathrm{b}}$ \\ a Teknik Komputer, Fakultas Teknik, Universitas Diponegoro \\ ${ }^{\mathrm{b}}$ Sekolah Vokasi, Universitas Diponegoro \\ Naskah Diterima : 11 September 2018; Diterima Publikasi : 20 Oktober 2018
}

DOI : 10.21456/vol8iss2pp181-186

\begin{abstract}
Beef needs have increased every year. So as the need for expensive beef even at certain times tends to rise. This is used by cheat seller to mix beef with pork because pork is relatively cheaper. This is very detrimental to consumers. Visually, many peoples (consumers) couldn't distinguish these two types of meat. Hence, we conduct research to distinguish both types of meat. The solution to solve the problem is using image processing techniques. The aim of this research was establised an application prototype to distinguish beef and pork with image processing techniques. Image processing method is used to distinguish the types of meat done by pre-processing, segmentation, feature extraction with geometrical moment invariant and K-NN classification. Geometric moment invariant method proposed to analyze beef and pork is done by extracting features from each images. This method can be used as a description of the form based on the moment theory. The results show that the image processing method and the K-NN classification with a value of $\mathrm{k}=3$ could significantly to analyze type of meat namely beef and pork. The other difference can be shown from the phi moment invariant value, especially the value of phi (1) and phi (2).
\end{abstract}

Keywords : Beef; Pork; Geometric Moment Invariant; Image Processing; K-NN classification

\begin{abstract}
Abstrak
Kebutuhan daging sapi setiap tahun mengalami kenaikan. Ditambah lagi harga jual daging sapi yang cenderung mahal bahkan pada saat tertentu cenderung naik. Hal ini dimanfaatkan oleh penjual daging nakal untuk mencampur daging sapi dengan daging babi karena harganya relatif lebih murah. Hal ini sangat merugikan konsumen. Secara visual, tidak banyak konsumen yang dapat membedakan kedua jenis daging ini. Sehingga perlu dilakukan penelitian untuk menganalisis perbedaan daging sapi dan babi. Salah satu bentuk invensi mengatasi masalah tersebut adalah menggunakan teknik pengolahan citra. Tujuan penelitian ini adalah membuat sebuah prototype untuk membedakan daging sapi dan babi dengan teknik-teknik pengolahan citra. Metode pengolahan citra digunakan untuk menganalisis daging dilakukan dengan pra-pengolahan, segmentasi, ekstraksi ciri moment invariant geometrik nilai phi(1) dan phi(2) serta klasifikasi K-NN. Metode moment invariant geometrik yang diusulkan untuk menganalisis daging sapi dan babi dilakukan dengan mengekstraksi ciri dari suatu citra. Metode ini dapat digunakan sebagai menjelaskan bentuk berdasarkan teori moment. Hasil penelitian menunjukkan bahwa metode pengolahan citra serta klasifikasi $\mathrm{K}-\mathrm{NN}$ dengan nilai $\mathrm{k}=3$ yang digunakan dalam penelitian secara signifikan dapat digunakan untuk menganalisis jenis daging sapi dan daging babi. Perbedaan lain dapat ditunjukkan dari nilai phi moment invariant terutama nilai phi(1) dan phi(2) daging sapi lebih kecil dari daging babi.
\end{abstract}

Kata kunci: Daging sapi; Daging babi; Momen Invarian Geometrik; Pengolahan citra; klasifikasi K-NN

\section{Pendahuluan}

Harga daging sapi yang meningkat setiap tahunnya dimanfaatkan oleh penjual daging nakal untuk mencampur daging sapi dan daging babi. Salah satu penyebab karena harga babi yang lebih murah (Komariah et al., 2009). Kasus pencampuran daging sapi dengan daging babi marak terjadi hingga saat ini (Assifa, 2017). Pencampuran daging babi dengan daging sapi tentu saja sangat merugikan bagi masyarakat Indonesia terutama bagi umat muslim

*) Penulis korespondensi: okydwin@gmail.com karena daging babi yang haram untuk dikonsumsi (Wahyudiyanta, 2017).

Secara visual pembeli tidak dapat membedakan jenis daging sapi dan babi. Meskipun banyak beredar cara-cara untuk membedakan daging, akan tetapi pengujian secara manual sering terjadi kesalahan karena terbatasnya penglihatan manusia dan tingkat subjektivitas dari penguji yang tinggi (Astuti, 2016).

Oleh karena itu, diperlukan sebuah sistem yang diharapkan dapat mengefisienkan pengujian secara visual. Budianita (2015), Untuk mengatasi 
permasalahan yang ada, maka dibuatlah suatu aplikasi yang berguna untuk menganalisis citra daging sapi dan daging babi menggunakan metode pengolahan citra di mulai dari pra-pengolahan citra, segmentasi, ekstraksi ciri, serta klasifikasi.

\section{Kerangka Teori}

Penelitian mengenai analisis citra daging sapi dan daging babi telah dilakukan oleh beberapa peneliti. Diantaranya adalah penelitian dilakukan oleh Wibowo, et al., (2016) yang membuat sebuah sistem analisis gambar daging sapi, babi, serta daging oplosan dengan ciri warna Hue, Saturation, Value dan ekstraksi ciri GLCM menggunakan klasifikasi Learning Vektor Quantization. Proses analisis citra terdiri dari proses pelatihan dan proses pengujian. Pada proses pelatihan, dilakukan proses ekstraksi ciri warna data citra latih menggunakan HSV dan ekstraksi ciri tekstur menggunakan GLCM. Hasil dari ekstraksi tersebut disimpan di dalam basis data. Sedangkan pada proses pengujian, hasil ekstraksi ciri warna dan tekstur data citra uji tidak disimpan tetapi langsung digunakan untuk proses klasifikasi menggunakan LVQ. Hasil dari proses ini berupa informasi apakah data latih tersebut daging babi atau sapi. Hasilnya menunjukkan bahwa akurasi keberhasilan tertinggi dengan rata-rata 94,81\% (Astuti, 2016).

Penelitian lain dilakukan oleh Masud (2015) mengenai bagaimana membedakan tekstur daging sapi dan babi dengan metode Principal Component Analysis dan jarak Euclidean. Proses awal yang dilakukan adalah membuat data latih dan data uji terlebih dahulu. Kemudian citra akan diuji coba dengan nilai threshold pada rentang keabuan antara 0255. Setelah dilakukan pemberian nilai threshold, dilanjutkan dengan segmentasi ukuran citra menjadi beberapa bagian yaitu dibagi menjadi 4 bagian sama rata. Proses ekstraksi ciri dilakukan setelah mendapatkan citra grayscale untuk selanjutnya diimplementasikan dalam metode PCA. Setelah itu dilakukan perbandingan kedekatan data latih dan data uji dengan metode jarak Euclidean. Keluaran yang dihasilkan berupa analisis daging sapi atau daging babi. Hasil aplikasi memberikan nilai akurasi sebesar $100 \%$ untuk 120 citra daging sapi dan daging babi.

Penelitian lainnya dilakukan oleh Budianita (2015) yaitu bagaimana mengetahui akurasi metode HSV, GLCM, serta klasifikasi K-Nearest Neighbour untuk mengelompokkan jenis daging sapi dan babi. Langkah awal yang dilakukan dalam penelitian ini adalah mengakuisisi citra menggunakan kamera digital untuk data latih dan data uji. Kemudian dilakukan pemotongan citra dengan ukuran 400x400 piksel untuk data latih. Citra potong selanjutnya di ektraks dengan ektraksi ciri orde kedua dan ektraksi warna HSV. Untuk ektraksi ciri orde kedua dilakukan konversi citra RGB ke citra aras keabuan terlebih dahulu sebelum dilakukan penghitungan. Dan dilakukan konversi citra
RGB ke citra HSV sebelum menghitung dengan ektraksi warna HSV. Hasil yang diperoleh adalah tingkat keakurasian tertinggi terletak pada pengujian tanpa background yaitu $88,75 \%$.

Penelitian terakhir dilakukan oleh Falah et al. (2016) mengenai bagaimana mendeteksi kualitas daging sapi degan menggunakan metode $k$-mean clustering pada perangkat mobile. Penelitian tersebut menggunakan ekstraksi ciri statistik orde satu dengan nilai mean dan variansi sebagai cirinya serta segmentasi k-mean cluster dengan berbagai variasi nilai $\mathrm{k}$. Nilai yang paling signifikan terdapat pada $\mathrm{k}=5$ untuk semua data yang digunakan dalam penelitian. Hasil akhir aplikasi diterapkan pada perangkat mobile smartphone.

\subsection{Daging}

Daging sapi memiliki warna merah pucat, merah keungu-unguan dan merah cerah (Komariah, dkk,2009). Seratnya tampak padat dan garis-garis terlihat jelas dengan tekstur yang kaku dan padat sehingga cukup sulit untuk direnggangkan (Lawrie, 1995).

Daging babi mempunyai kandungan lemak yang sangat tinggi. Daging babi memiliki tekstur yang lembut dan empuk, tetapi jika dikonsumsi daging babi sulit dicerna (As Syaukani, 2009). Risiko yang dialami oleh orang yang memakan daging babi yang terjangkiti cacing babi adalah meningkatnya kolesterol dan memperlambat protein dalam tubuh serta menjadi penyebab utama kanker anus dan kolon.

Menurut Sembiring (2004), Kualitas daging babi dapat diuji berdasarkan nilai $\mathrm{pH}$, daya ikat air, kadar air, warna, keempukan dan lemak intramuskuler dari daging tersebut. BSN (2008), Daging babi yang baik memiliki $\mathrm{pH}$ yang rendah karena menyebabkan daging mempunyai struktur yang terbuka dengan warna merah cerah, rasa yang lebih enak dan lebih tahan terhadap mikroba. Kandungan air dalam daging babi berpengaruh dalam perkembangan mikroba dalam daging (Sembiring, 2004).

\subsection{Pengolahan Citra}

Operasi pengolahan citra dibagi menjadi 3 tingkat pengolahan, yaitu sebagai berikut (Jain, 1989);

1. Pengolahan Tingkat Rendah

Pengolahan tingkat rendah merupakan operasi awal dalam pengolahan citra yang berfungsi untuk pengurangan noise, melakukan perbaikan citra serta pemugaran citra.

2. Pengolahan Tingkat Menengah

Pengolahan tingkat menengah berfungsi untuk membagi citra menurut kemiripan piksel, menjelaskan objek dan mengenali objek secara terpisah.

3. Pengolahan Tingkat Tinggi

Pengolahan tingkat tinggi bertujuan untuk menganalisis citra. 
Metode segmentasi yang digunakan dalam penelitian ini adalah pengambangan yang berfungsi untuk mengubah citra dengan skala keabuan, yang mempunyai kemungkinan nilai lebih dari 2, ke citra biner yang memiliki 2 nilai (yaitu 0 dan 1) (Gonzales, 2008).

Segmentasi merupakan suatu metode untuk membagi dan mempartisi citra menjadi beberapa daerah dengan kemiripan piksel yang sama (Sutoyo, et al., 2009). Beberapa metode segmentasi diantaranya pengambangan, watershed, region growing, $k$-mean clustering, dan lain-lain.

$\mathrm{K}$-mean clustering merupakan teknik segmentasi citra berdasarkan intensitas warna (Agusta, 2007). Metode ini memiliki asumsi bahwa objek-objek yang akan di bagi/partisi memiliki intensitas warna yang berbeda dan setiap objek memiliki warna yang hampir seragam. Proses partisi dilakukan dengan membagi histogram citra (Irwanto, 2012). Algoritma k-mean clustering dijelaskan sebagai berikut:

1. Mula-mula dicari intensitas maksimum dan minimum citra.

2. Dari intensitas minimum ke maksimum dilakukan pembagian sejumlah $\mathrm{N}$ histogram yang berfungsi untuk menentukan jumlah objek.

3. Dari pembagian, histogram akan terbagi menjadi cluster (kelompok). Kemudian setiap titik akan dikelompokkan ke cluster terdekat sehingga hasil akhir dari proses ini adalah jumlah warna pada gambar menjadi $\mathrm{N}$.

4. Langkah selanjutnya adalah mencari ratarata/mean atas seluruh titik pada setiap cluster, kemudian mengganti warna seluruh titik di dalam cluster-cluster tersebut dengan rata-rata setiap cluster.

\subsection{Ekstraksi Ciri Moment invariant Geometrik}

Gonzales (2008), Moment invariant adalah kumpulan moment yang menjelaskan karakteristik global dari bentuk citra dan menmberikan informasi tipe-tipe geometri citra. Penggunaan moment invariant untuk setiap citra dengan ukuran $\mathrm{M} \times \mathrm{N}$ piksel, dihitung dengan menggunakan persamaan (1) berikut.

$$
m_{p q=\sum_{x=1}^{M} \sum_{y=1}^{N} x^{p} y^{p} f(x, y)}
$$

nilai $\mathrm{f}(\mathrm{x}, \mathrm{y})$ merupakan nilai piksel pada koordinat $(\mathrm{x}, \mathrm{y})$.

Gonzales (2008), sedangkan invarian translasi dapat dihitung dengan menggunakan central moment yang di jelaskan dengan persamaan (2).

$$
\mu_{p q}=\sum_{x=0}^{M-1} \sum_{y=0}^{N-1}(x-\bar{x})^{p}(y-\bar{y})^{q} f(x, y)
$$

dimana $\bar{x}=\frac{m_{10}}{m_{00}}, \bar{y}=\frac{m_{01}}{m_{00}}$

Nilai Central moment yang dinormalisasi di jelaskan oleh persamaan (3).

$$
\eta_{p q}=\frac{\mu_{p q}}{\left(\mu_{00}\right)^{\lambda}}
$$

dengan $\lambda=\frac{(i+j)}{2}+1$
Berdasarkan nilai momen ternormalisasi, selanjutnya $\mathrm{Hu}$ menjelaskan tujuh nilai invariant yang di sebut dengan moment invariant yang ditunjukkan oleh persamaan (4).

$$
\begin{aligned}
\phi_{1}= & \eta_{20}+\eta_{02} \\
\phi_{2}= & \left(\eta_{20}+\eta_{02}\right)^{2}+4 \eta_{11}^{2} \\
\phi_{3}= & \left(\eta_{30}-3 \eta_{12}\right)^{2}+\left(3 \eta_{21}-\eta_{03}\right)^{2} \\
\phi_{4}= & \left(\eta_{30}+\eta_{12}\right)^{2}+\left(\eta_{21}+\eta_{03}\right)^{2} \\
\phi_{5}= & \left(\eta_{30}-3 \eta_{12}\right)\left(\eta_{30}+\eta_{12}\right)\left[\left(\eta_{30}+\eta_{12}\right)^{2}-3\left(\eta_{21}+\eta_{03}\right)^{2}\right] \\
& +\left(3 \eta_{21}-\eta_{03}\right)\left(\eta_{21}+\eta_{03}\right)\left[3\left(\eta_{30}+\eta_{12}\right)^{2}-\left(\eta_{21}+\eta_{03}\right)^{2}\right] \\
\phi_{6}= & \left(\eta_{20}-\eta_{02}\right)\left[\left(\eta_{30}+\eta_{12}\right)^{2}-3\left(\eta_{21}+\eta_{03}\right)^{2}\right] \\
& +4 \eta_{11}\left(\eta_{30}+\eta_{12}\right)\left(\eta_{21}+\eta_{03}\right) \\
\phi_{7}= & \left(3 \eta_{21}-\eta_{03}\right)\left(\eta_{30}+\eta_{12}\right)\left[\left(\eta_{30}+\eta_{12}\right)^{2}-3\left(\eta_{21}+\eta_{03}\right)^{2}\right] \\
& +\left(3 \eta_{12}-\eta_{30}\right)\left(\eta_{21}+\eta_{03}\right)\left[3\left(\eta_{30}+\eta_{12}\right)^{2}-\left(\eta_{21}+\eta_{03}\right)^{2}\right]
\end{aligned}
$$

Nilai moment invariant tersebut tidak berubah terhadap translasi, perubahan skala, pencerminan (mirroring) dan rotasi.

\section{Metode}

Prosedur yang menjelaskan langkah-langkah yang digunakan dalam penelitian ini adalah:

1. Pengembangan algoritma analisis citra digital daging sapi dan babi yang diambil dari kamera smartphone HP Lenovo A7000.

2. Membuat algoritma pra-olah citra ekualisasi histogram untuk meningkatkan kualitas citra yang akan digunakan sebagai input segmentasi, metode segmentasi thresholding dan k-mean clustering dengan tujuan untuk membandingkan metode segmentasi yang lebih baik digunakan untuk jenis citra daging, menghitung moment invariant dengan mengesktrak tujuh nilai phi dari masing-masing citra, serta teknik klasifikasi KNN dengan variasi nilai $\mathrm{K}$ yang siginifikan untuk membedakan kedua jenis daging.

3. Menguji algoritma pra-pengolahan ekualisasi, segmentasi k-mean clustering dan threshold, perhitungan moment invariant geometric, klasifikasi KNN untuk menentukan membedakan kedua jenis citra daging sapi dan babi.

Dalam penelitian ini menggunakan 50 sampel daging yang terbagi ke dalam 25 jenis daging sapi dan 25 jenis daging babi. Setiap sampel citra daging diakuisisi dengan menggunakan kamera digital. Hasil akuisisi citra digital kemudian di ubah ukurannya dari 1,5 Mb menjadi $210 \mathrm{~kb}$ dengan ekstensi penyimpanan .jpg. Kemudian citra digital hasil akuisisi di atur ukuran piksel dan cropping obyek untuk memudahkan pada saat memasukkan citra sebagai input simulasi.

Langkah selanjutnya adalah pembuatan Graphical User Interface (GUI) aplikasi dengan menggunakan Matlab 2016. Sedangkan perangkat lunak pendukung 
aplikasi diantaranya adalah sebagai berikut: Sistem Operasi Windows 8, Microsoft Word 2013.

Sedangkan perangkat keras yang digunakan dalam penelitian, diantaranya; Laptop Asus X201E dengan sistem operasi Windows 8 Pro 64 bit, Prosesor Intel ${ }^{\circledR}$ Celeron® CPU 1007U @1.50GHz dan RAM 12 GB. Perangkat ini digunakan untuk penunjang kinerja aplikasi penelitian dan pembuatan aplikasi.

Diagram alir penelitian ditunjukkan pada Gambar 1.

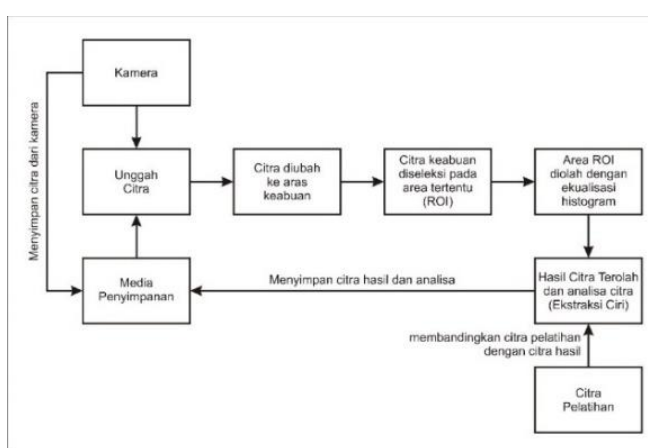

Gambar 1. Diagram blok sistem proses analisis jenis daging sapi dan babi

Gambar 1 merupakan langkah proses aplikasi analisis daging secara keseluruhan. Pada tahap awal dilakukan pengambilan sampel daging dengan load citra kamera ponsel. Citra yang sudah diload dikonversi ke citra keabuan 8 bit untuk pemrosesan citra lebih lanjut. Hasil citra keabuan diseleksi berdasarkan area yang diminati (Region Of Interest/ ROI). Area terseleksi selanjutnya diolah menggunakan metode ekualisasi histogram untuk meningkatkan kualitas objeknya. Setelah hasil citra terolah didapat, dilakukan proses ekstraksi ciri menggunakan moment invariant geometrik untuk menganalisis kedua jenis daging tersebut. Hasil ekstraksi ciri kemudian diklasifikasi dengan metode KNN untuk memudahkan pembacaan jenis daging tersebut.

\section{Hasil dan Pembahasan}

Penelitian ini menerapkan tahap-tahap prapengolahan, pengolahan citra, analisis maupun klasifikasi. Langkah awal penelitian sebuah citra masukan di pra-olah dengan menggunakan beberapa teknik seperti pengubahan brightness, contrast, histogram ekualisasi. Menu histogram citra yang ditambahkan pada aplikasi berfungsi untuk melihat kualitas citra masukan sebelum diolah. Dari tiga teknik pra-olah yang digunakan kemudian output dari praolah digunakan sebagai masukan langkah selanjutnya yaitu segmentasi. Dalam penelitian ini kami menggunakan dua teknik segmentasi yaitu thresholding dan k-mean clustering. Pada teknik thresholding digunakan tiga jenis threshold yang berbeda, hal ini bertujuan untuk membandingkan ketiga jenis threshold yang memiliki hasil keluaran yang bagus. Ketiga jenis threshold yang digunakan yaitu adapthresh, otsuthresh, dan graythresh. Langkah selanjutnya adalah melakukan perhitungan moment invariant geometrik dari masing-masing citra masukan yaitu daging babi dan daging sapi. Hasil keluaran dari moment invariant digunakan sebagai input klasifikasi KNN.

Hasil pengolahan citra, segmentasi k-mean cluster serta hasil perhitungan ekstraksi ciri moment invariant geometrik citra digital daging babi (B1.jpg) ditunjukkan oleh Gambar 2.

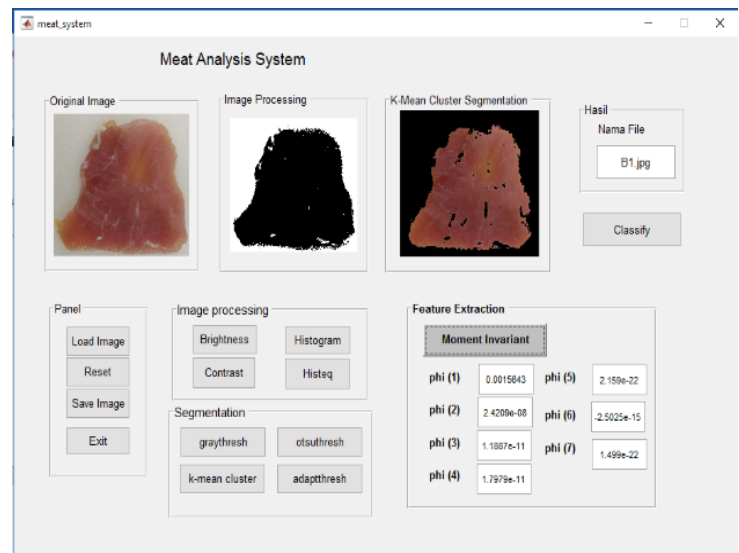

Gambar 2. Hasil moment invariant citra B1.jpg

Gambar 2 menunjukkan hasil pengolahan citra daging babi dengan teknik segmentasi otsuthresh, kmean clustering, serta hasil perhitungan moment invariant geometrik dengan phi $(1)=0.0015643$, phi $(2)=2.42 \mathrm{E}-08$. Sedangkan hasil moment invariant geometrik untuk phi(3), phi(4), phi(5), phi(6), phi(7) memiliki hasil yang sangat kecil sehingga tidak dapat digunakan sebagai analisis.

Teknik pra-pengolahan lain yang digunakan dalam penelitian ini adalah brightness yang berfungsi untuk mencerahkan citra masukan, contrast berfungsi untuk menambah kontras gambar, serta histogram ekualisasi yang berfungsi untuk merata-ratakan piksel citra sehingga hasil pra-pengolahan citra daging memiliki kualitas yang lebih baik daripada citra aslinya.

Teknik segmentasi dengan mempartisi objek yang diminati (Region of Interest /ROI) dilakukan dengan teknik thresholding dengan berbagai jenis threshold seperti adapthresh, graythresh, otsuthresh serta k-mean clustering. Hasil penelitian menunjukkan bahwa klasifikasi $k$-mean clustering memiliki hasil yang lebih baik untuk di aplikasikan pada citra daging sapi dan daging babi. Sedangkan pemilihan nilai $\mathrm{k}$ pada hasil klasifikasi KNN dilakukan berdasarkan pengujian nilai $\mathrm{K}=1$ sampai dengan $\mathrm{K}=5$. Hasil klasifikasi cukup signifikan dapat digunakan untuk memisahkan kedua jenis daging ditunjukkan saat nilai $\mathrm{K}=3$.

Hasil perhitungan ekstraksi ciri moment invariant geometrik citra daging babi (B9.jpg) ditunjukkan oleh Gambar 3. 


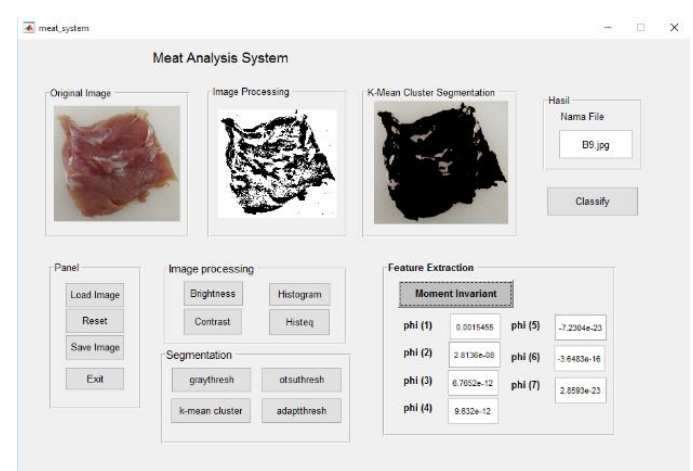

Gambar 3. Hasil moment invariant geometrik citra B9.jpg

Gambar 3 menunjukkan hasil pengolahan citra daging babi dengan teknik segmentasi otsu, k-mean clustering, serta hasil perhitungan moment invariant geometrik dengan nilai phi $(1)=0.0015455$, phi $(2)=$ 2.81E-08. Sedangkan hasil moment invariant geometrik untuk phi(3), phi(4), phi(5), phi(6), phi(7) memiliki hasil yang sangat kecil sehingga tidak dapat digunakan sebagai analisis.

Tabel 1 berikut menunjukkan hasil perhitungan moment invariant geometrik untuk seluruh citra daging babi yang diberikan nama file B1.jpg B10.jpg.

Tabel 1. Hasil perhitungan moment invariant geometrik daging babi

\begin{tabular}{|c|c|c|c|c|c|c|c|}
\hline $\begin{array}{c}\text { Nama } \\
\text { file }\end{array}$ & Phi (1) & Phi (2) & Phi (3) & Phi (4) & Phi (5) & Phi (6) & Phi (7) ${ }^{5} 5 . j p g$ \\
\hline B1.jpg & 0.0015643 & $2.42 \mathrm{E}-08$ & 0.0000 & 0.0000 & 0.0000 & -0.0000 & $0.0008^{6 . j} \mathrm{pg}$ \\
\hline B2.jpg & 0.0014895 & $1.01 \mathrm{E}-07$ & 0.0000 & 0.0000 & -0.0000 & -0.0000 & 0.0000 \\
\hline B3.jpg & 0.0015123 & $3.29 \mathrm{E}-07$ & 0.0000 & 0.0000 & 0.0000 & 0.0000 & $-0.00 \$ 7 . j p g$ \\
\hline B4.jpg & 0.001499 & $6.17 \mathrm{E}-08$ & 0.0000 & 0.0000 & 0.0000 & 0.0000 & -0.0000 \\
\hline B5.jpg & 0.0016996 & 7.87E-07 & 0.0000 & 0.0000 & 0.0000 & 0.0000 & $0.0008_{8}$ \\
\hline B6.jpg & 0.0017529 & $5.72 \mathrm{E}-07$ & 0.0000 & 0.0000 & 0.0000 & 0.0000 & $0.0000^{8 . j p g}$ \\
\hline B7.jpg & 0.0014108 & $9.29 \mathrm{E}-08$ & 0.0000 & 0.0000 & 0.0000 & 0.0000 & 0.0000 \\
\hline B8.jpg & 0.001734 & 4.84E- 08 & 0.0000 & 0.0000 & 0.0000 & -0.0000 & $-0.00 \mathscr{\Theta} 9 . j p g$ \\
\hline B9.jpg & 0.0015455 & $2.81 \mathrm{E}-08$ & 0.0000 & 0.0000 & -0.0000 & -0.0000 & 0.0000 \\
\hline B10.jpg & 0.0014657 & $1.37 \mathrm{E}-07$ & 0.0000 & 0.0000 & -0.0000 & 0.0000 & $0.00 @ 10 . j p g$ \\
\hline
\end{tabular}

Hasil perhitungan ekstraksi ciri moment invariant geometrik citra daging sapi (S1.jpg) ditunjukkan oleh Gambar 4.

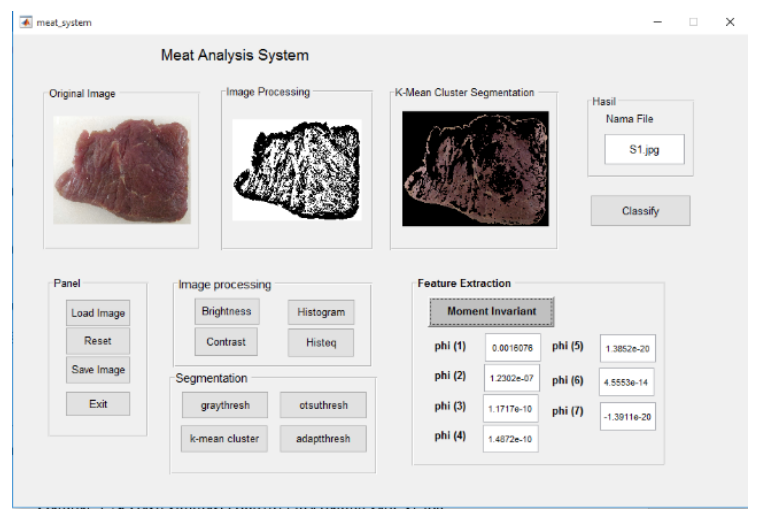

Gambar 4. Hasil perhitungan moment invariant citra daging sapi S1.jpg
Gambar 4 menunjukkan hasil pengolahan citra daging sapi dengan teknik segmentasi otsu, k-mean clustering, serta hasil perhitungan moment invariant geometrik dengan nilai phi $(1)=0.0016076$, phi $(2)=$ 1.23E-07. Sedangkan hasil moment invariant geometrik untuk phi (3), phi (4), phi (5), phi (6), phi (7) memiliki hasil yang sangat kecil sehingga tidak dapat digunakan sebagai analisis.

Menu Segmentation Image Processing yang dihasilkan dari Gambar 2, Gambar 3, dan Gambar 4 menunjukkan bahwa segmentasi thresholding tidak dapat digunakan untuk membedakan kedua jenis citra daging, sedangkan k-mean clustering memberikan hasil citra daging sapi berwarna lebih gelap dibanding citra daging babi.

Hasil perhitungan ekstraksi ciri moment invariant geometrik untuk seluruh citra digital daging sapi yang diberi nama S1.jpg - S10.jpg ditunjukkan oleh Tabel 2 berikut.

Tabel 2. Hasil perhitungan moment invariant geometrik seluruh daging sapi

\begin{tabular}{|c|c|c|c|c|c|c|c|}
\hline $\begin{array}{c}\text { Nama } \\
\text { file }\end{array}$ & $\begin{array}{l}\mathrm{Phi} \\
(1)\end{array}$ & $\begin{array}{l}\text { Phi } \\
\text { (2) }\end{array}$ & $\begin{array}{l}\text { Phi } \\
(3)\end{array}$ & $\begin{array}{l}\text { Phi } \\
(4)\end{array}$ & $\begin{array}{l}\text { Phi } \\
(5)\end{array}$ & Phi (6) & $\begin{array}{l}\text { Phi } \\
(7)\end{array}$ \\
\hline S1.jpg & $\begin{array}{c}0.001 \\
608\end{array}$ & $\begin{array}{l}1.23 \\
\text { E-07 }\end{array}$ & 0.000 & 0.000 & 0.000 & -0.000 & 0.000 \\
\hline S2.jpg & $\begin{array}{c}0.001 \\
495\end{array}$ & $\begin{array}{l}9.73 \\
\text { E-09 }\end{array}$ & 0.000 & 0.000 & $\begin{array}{c}- \\
0.000\end{array}$ & -0.000 & 0.000 \\
\hline S3.jpg & $\begin{array}{c}0.001 \\
368\end{array}$ & $\begin{array}{l}6.41 \\
\text { E-08 }\end{array}$ & 0.000 & 0.000 & 0.000 & 0.000 & -0.00 \\
\hline S4.jpg & $\begin{array}{c}0.001 \\
407\end{array}$ & $\begin{array}{l}1.75 \\
\text { E- } 07\end{array}$ & 0.000 & 0.000 & 0.000 & 0.000 & -0.00 \\
\hline Phi (t) ${ }^{5} 5 . j p g$ & $\begin{array}{c}0.001 \\
679\end{array}$ & $\begin{array}{l}2.01 \\
\text { E-07 }\end{array}$ & 0.000 & 0.000 & 0.000 & 0.000 & 0.000 \\
\hline $\begin{array}{l}\overline{0.0008^{6 . j}} \\
0.0000\end{array}$ & $\begin{array}{c}0.001 \\
531\end{array}$ & $\begin{array}{l}5.46 \\
\text { E-08 }\end{array}$ & 0.000 & 0.000 & 0.000 & 0.000 & 0.000 \\
\hline $\begin{array}{l}-0.00 \$ 7 . j p g \\
-0.0000\end{array}$ & $\begin{array}{c}0.001 \\
309\end{array}$ & $\begin{array}{l}2.26 \\
\text { E-08 }\end{array}$ & 0.000 & 0.000 & 0.000 & 0.000 & 0.000 \\
\hline $\begin{array}{l}0.00098 . j p g \\
0.0000 \\
0.0000\end{array}$ & $\begin{array}{c}0.001 \\
235\end{array}$ & $\begin{array}{l}9.33 \\
\text { E- } 08\end{array}$ & 0.000 & 0.000 & 0.000 & -0.00 & -0.00 \\
\hline $\begin{array}{l}-0.00 \oplus 99 . j p g \\
0.0000\end{array}$ & $\begin{array}{c}0.001 \\
392\end{array}$ & $\begin{array}{l}7.62 \\
\text { E- } 09\end{array}$ & 0.000 & 0.000 & -0.00 & -0.00 & 0.000 \\
\hline 0.00@10.jpg & $\begin{array}{c}0.001 \\
418 \\
\end{array}$ & $\begin{array}{l}2.81 \\
\mathrm{E}-07 \\
\end{array}$ & 0.000 & 0.000 & -0.00 & 0.000 & 0.000 \\
\hline
\end{tabular}

Hasil klasifikasi dengan menggunakan metode $\mathrm{K}$ NN (Classification Learner) dengan $\mathrm{k}=3$ ditunjukkan pada Gambar 5 berikut.

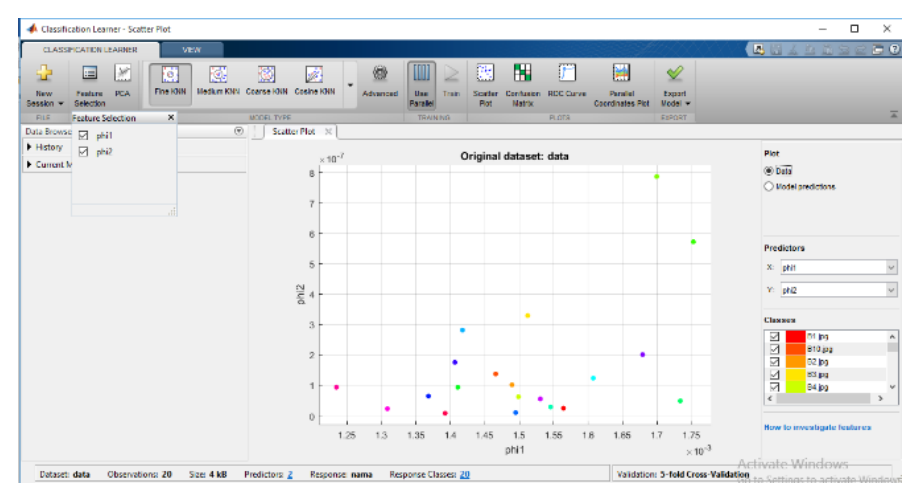

Gambar 5. Hasil K-NN dengan k=3 


\section{Kesimpulan}

Berdasarkan hasil simulai, dapat disimpulkan beberapa hal sebagai berikut.

1. Metode pengolahan citra yang digunakan pada penelitian ini adalah segmentasi thresholding tidak dapat digunakan untuk membedakan kedua jenis citra daging, sedangkan hasil k-mean clustering citra daging sapi berwarna lebih gelap dibanding citra daging babi.

2. Hasil klasifikasi dengan metode KNN dilakukan dengan mengubah nilai $K$. Hasil penelitian menunjukkan nilai $\mathrm{K}=3$ secara signifikan dapat digunakan untuk memisahkan kedua jenis citra daging.

3. Hasil ekstraksi ciri moment invariant geometrik citra digital daging sapi memiliki phi $(1)=0.0017$ dan phi $(2)=1.23 \mathrm{E}-07$ lebih besar daripada daging babi yang memiliki nilai phi $(1)=0.0013$, phi $(2)=$ 2.42E-08 sedangkan nilai phi(3), phi(4), phi(5), phi(6), dan phi(7) dari kedua jenis citra daging tidak dapat digunakan sebagai pembeda.

Saran untuk pengembangan hasil penelitian. Penelitian ini dapat dikembang lebih lanjut untuk membedakan kedua jenis daging sapi dan daging babi berbasis mobile.

\section{Daftar Pustaka}

Agusta, Y, 2007. K-Means-Penerapan, Permasalahan dan Metode Terkait Jurnal Sistem dan Informatika, 3, 47-60.

Assifa, F., 2017. Polisi Jember Tangkap Penjual Daging Sapi yang Dicampur Daging Babi, http://regional.kompas.com/read/2017/02/22/0626 5601/polisi.jember.tangkap.penjual.daging.sapi.ya ng.dicampur.daging.babi, diakses tanggal $14 \mathrm{Mei}$ 2017.

Astuti, W.R, 2016. Klasifikasi citra daging sapi dan daging babi berdasarkan ciri warna dan tekstur, Skripsi UIN Sunan Kalijaga, Yogyakarta, http://digilib.uin-suka.ac.id/22203/

As Syaukani, M., 2009. Mengenal Beda Daging Sapi dan Daging Babi, Hidayatullah.

Budianita, E., Jasril, J., dan Handayani, L., 2015. Implementasi pengolahan citra dan klasifikasi knearest neighbour untuk membangun aplikasi pembeda daging sapi dan babi berbasis web, J. Sains dan Teknol. Ind., 12 (2), 242-247.

BSN, 2008. Standar Nasional Indonesia 3932:2008 Mutu karkas dan daging sapi, http://logis.co.id/assets/pdf/beef.pdf di akses 23 Oktober 2018.
Falah, R.F., Nurhayati, O.D. dan Martono, K.T., 2016, Aplikasi pendeteksi kualitas daging menggunakan segmentasi region of interest berbasis mobile, J. Teknol. dan Sist. Komput., 4 (2), 333-343.

Food and Agriculture Organization, Composition of Meat, 2017. http://www.fao.org/ag/againfo/themes/en/meat/ba ckgr_composition.html, diakses tanggal $23 \mathrm{Mei}$ 2018.

Gonzalez, R.C., dan Woods, R.E., 2008. Digital Image Processing. Pearson Education, 2008.

Irwanto, Yudhi, P., Rully, S., 2013. Optimasi kinerja algoritma klasterisasi K-means untuk kuantisasi warna citra, Fakultas Teknologi Informasi, Institut Teknologi Sepuluh Nopember, Surabaya, http://ejurnal.its.ac.id/index.php/teknik/article/vie w/631 di akses 23 Oktober 2018

Jain, A., 1989. Fundamentals of Digital Image Processing.

Komariah, S. Rahayu, Sarjito, 2009. Sifat fisik daging sapi, kerbau dan domba pada lama postmortem yang berbeda. Jurnal Peternakan, vol.33,no.3,https://journal.ugm.ac.id/buletinpetern akan/article/view/115

Lawrie, R.A., 1995. Ilmu Daging Diterjemahkan oleh Aminuddin Parakkasi, Universitas Indonesia Press, Jakarta, http://library.um.ac.id/freecontents/index.php/buku/detail/ilmu-daging-olehr-a-lawrie-penerjemah-aminuddin-parakkasi17342.html diakses 23 Oktober 2018

Masud, 2015. Implementasi principal component analysis (PCA) dan euclidean distance untuk identifikasi citra daging sapi dan daging babi, Skripsi Fakultas Ilmu Komputer, Universitas Dian Nuswantoro, Semarang.

Wahyudiyanta, I., 2017. Begini Cara Membedakan Daging Sapi dan Babi, http://news.detik.com/jawatimur/3218862/beginicara-membedakan-daging-sapi-dan-babi, diakses tanggal 16 Mei 2017.

Wibowo, S.A., Hidayat, B. dan Sunarya, U., 2016, Simulasi dan analisis pengenalan citra daging sapi dan daging babi dengan metode GLCM, Prosiding SENIATI, Malang.

Sutoyo, T., Mulyanto, E., Suhartono, E., Nurhayati, O.D. dan Wijanarto, 2009. Teori Pengolahan Citra Digital, Penerbit ANDI, Yogyakarta,.

Siagian, P.H., Priyanto, R. Sembiring, R., 2004. Kualitas daging babi dengan pemberian zeolit dan tepung darah sebagai sumber protein dalam ransum, media peternakan, Journal of Animal Science and Technology, 27 (1). 